\title{
Civic Culture in the Values of Local Wisdom of the Dayak Kantuk Community in Bika Village
}

\author{
Natalia Itut ${ }^{1)}$, Jagad Aditya Dewantara ${ }^{2)}$, Bistari ${ }^{3)}$ \\ ${ }^{1}$ Program Studi Pendidikan Pancasila dan Kewarganegaraan Fakultas Keguruan dan Ilmu Pendidikan \\ ${ }^{2}$ Program Studi Pendidikan Matematika Fakultas Keguruan dan Ilmu Pendidikan \\ Universitas Tanjungpura, Jl. Prof. Dr. H. Hadari Nawawi, Pontianak, Indonesia 78124 \\ Corresponding Author: Jagad Aditya Dewantara, Email: jagad02@fkip.untan.ac.id
}

History: Received 09/12/2021 | Revised 15/12/2021 | Accepted 04/01/2022 | Published 31/01/2022

\begin{abstract}
Culture is a characteristic preserved by ethnic groups in the social environment. The existence of cultural preservation provides a space embedded in community groups in realizing cultural consistency from generation to generation, such as the gawai makai taun tradition as a Kantuk Dayak custom held in May every year. This article aims to analyze the local wisdom of the community as a tradition attached to the Kantuk Dayak tribal group in carrying out the Gawai tradition. This study is essential to be carried out, especially for the preparation, process, and preservation of the values of local wisdom of the gawai tradition in Bika Village. This study uses a qualitative approach with contemporary ethnographic methods. The informants were village heads, community leaders, local communities, migrant communities, and traditional stakeholders, totaling nine informants. The results obtained that the value of local wisdom of the Kantuk Dayak community upholds solidarity in carrying out the gawai makai taun tradition, which means the community's gratitude to God for the blessings and fortune given in the form of appreciation for the abundant rice harvest. In addition, the Gawai Makai Taun tradition brings the community in Bika Village to strengthen cooperation in preparing and implementing the Makai Taun tradition, which contains local wisdom values that lead to a civic culture such as the ceremony carried out by the community in Bika Village to prepare gawai and implement gawai together. Keywords: Civic Culture, Values of local wisdom, Kantuk Dayak Community
\end{abstract}

\begin{abstract}
Abstrak. Kebudayaan menjadi suatu ciri khas yang dilestarikan kelompok etnis dalam lingkungan sosial. adanya pelestarian budaya memberikan ruang yang tertanam pada kelompok masyarakat dalam mewujudkan konsitensi budaya dari generasi ke genarasi seperti tradisi gawai makai taun sebagai adat istiadat Dayak Kantuk yang dilaksanakan pada bulan Mei setiap tahunnya. Artikel ini bertujuan untuk mengalisis kearifan lokal masyarakat sebagai tradisi yang melekat pada kelompok suku Dayak Kantuk dalam melaksanakan tradisi Gawai. Kajian ini menjadi penting untuk dilakukan terutama untuk persiapan, proses serta pelestarian nilai-nilai kearifan lokal tradisi gawai di Desa Bika. Penelitian ini menggunakan pendekatan kualitatif dengan metode etnografi kontemporer. Informan yang diambil yakni kepala desa, tokoh masyarakat, masyarakat setempat, masyarakat pendatang dan pemangku adat. Jumlah seluruhnya 9 orang informan. Hasil penelitian yang diperoleh bahwa Nilai kearifan lokal masyarakat Dayak Kantuk menjunjung tinggi solidaritas dalam melaksanakan tradisi gawai makai taun dimaknai rasa syukur masyarakat kepada Tuhan atas berkat dan rejeki yang diberikan dalam bentuk syukur terhadap panen padi yang melimpah. Disamping itu, tradisi gawai makai taun membawa masyarakat di Desa Bika untuk mempererat kerjasama dalam mempersiapkan dan melaksanakan tradisi gawai makai taun terkandung nilai-nilai kearifan lokal yang mengarah kepada.budaya kewarganegaraan seperti upacara gawai dilakukan masyarakat di Desa Bika untuk mempersiapan gawai dan melaksanakan gawai bersama-sama.
\end{abstract}

Kata kunci: Budaya Kewarganegaraan, Nilai-nilai kearifan lokal, Dayak Kantuk 


\section{INTRODUCTION}

The development of culture into a unified whole cannot be separated from people's lives. Culture is a habit carried out by people from certain ethnic groups. On the other hand, culture is preserved by all members of the tribe with a broad understanding of the minds and traditions of the community in a social environment (Bahri, 2012). The preservation of culture provides space embedded in community groups to realize cultural consistency from generation to generation. There are customs of the Dayak Kantuk community, such as holding a gawai makai taun. This is a form of community solidarity in Bika Village to carry out the gawai makai taun together (Malasari, 2017). The gawai makai taun tradition is interpreted with religious value in the sense of expressing gratitude for the Dayak Kantuk community to God for the fortune given by God/Petara in the form of abundant rice harvests during farming as an expression of appreciation, the community's customs provide offerings with ritual ceremonies to the giver of sustenance (Levanda, 2018). Device activities are held to avoid burdens, logs, and obstacles. This belief is still firmly held today among the Dayak Kantuk community. This gawai tradition expresses gratitude to God for the blessings and abundance of fortune that God has given in the sense of the Dayak Kantuk language being grateful to Jubata. The tradition aims to strengthen the ties of brotherhood between the
Dayak Kantuk people to continue to instill an attitude of solidarity and hold fast to the values of local wisdom around them (Feriandi, 2017).

The Dayak Kantuk community is one of the ethnic groups in West Kalimantan that has the local wisdom of the Annual Gawai. The Gawai day is determined every May, called the Makai Taun. The implementation of this gawai day is accompanied by nyengkelan of the tools used for farming so that when farming the following year, it can run smoothly. In addition, the Makai taun culture will be carried out annually by the Dayak tribe, believing that the next year will be protected from danger (Korniadi \& Purwanto, 2019). On the other hand, the Gawai Makai Taun tradition contains local wisdom values that lead to a civic culture, such as a gawai preparation ceremony carried out by the community in Bika Village to prepare gawai and carry out gawai together.

Furthermore, the Bika community is dominantly the Dayak Kantuk ethnic group that upholds the Gawai Makai Taun ceremony. On the other hand, tradition has a significant value for people's lives because tradition contains the value of gratitude, the value of mutual respect, and tolerance for the community in the social environment (Jung, 2014). Therefore, it is necessary to explore the values of local wisdom to open up public understanding that it is essential to preserve local wisdom as a characteristic of the local community. 
This gawai tradition aims to strengthen the air ties in the Dayak Kantuk community. This must be maintained and preserved by the Dayak Kantuk community so that the customs and traditions of the people in Bika Village are preserved.

This article is intended to add to the study of the local wisdom of the community as a tradition inherent in the Dayak Kantuk tribal group in carrying out the Gawai tradition. This study is essential to be carried out, especially for the preparation, process, and preservation of the values of local wisdom of the gawai tradition in West Kalimantan. The purpose of this research is based on the following research questions as follows:

1) How to prepare for the gawai tradition of the Dayak Kantuk community in Bika Village?

2) How is the process of gawai tradition in shaping the citizenship culture of the Dayak Kantuk community in Bika Village?

3) What are the obstacles faced by the Dayak Kantuk community in Bika Village in preserving the values of local wisdom?

\section{RESEARCH METHODS}

This study uses a qualitative approach with contemporary ethnographic methods because local wisdom is an important study to analyze the gawai makai tuan tradition from the culture of the Dayak community to be preserved as the cultural values of the Dayak Kantuk community in Bika Village (Creswell, 2014). Meanwhile, this study reveals social activities and attitudes of community cultural groups towards local wisdom through citizenship culture. Contemporary ethnography must be able to create a problemsolving work so that its implications can be seen. Ethnographic models for understanding the meaning of culture today are likely to be applied by contemporary studies such as communication, cultural studies, economics, sociology, psychology, education, journalism, social studies, and even other humanities studies (Haybi \& Shoshana, 2021).

The research participation involved the Dayak Kantuk community group in Bika Village. The language used by the community is the Kantuk language. This research was conducted in Bika Village, Bika District, Kapuas Hulu Regency, West Kalimantan. The people who live in Bika Village are indigenous people from the 1990s until now. The researcher uses the purposive sampling technique to determine the source of the informant's data (Rutten \& Soetaert, 2013). Informants were taken only from indigenous people and immigrant communities. This immigrant community starts from a marriage relationship such as the Bika village community marrying someone outside the village or district after following their husband or wife to live in Bika Village; then they are called immigrant communities. Researchers observed and conducted interviews with community participants for about a whole month to investigate how 
citizenship culture has an essential role for the community in preserving the values of local wisdom so as not to be eroded by increasingly advanced globalization.

Table 1.

Administrative Map of Bika Village, Bika

District

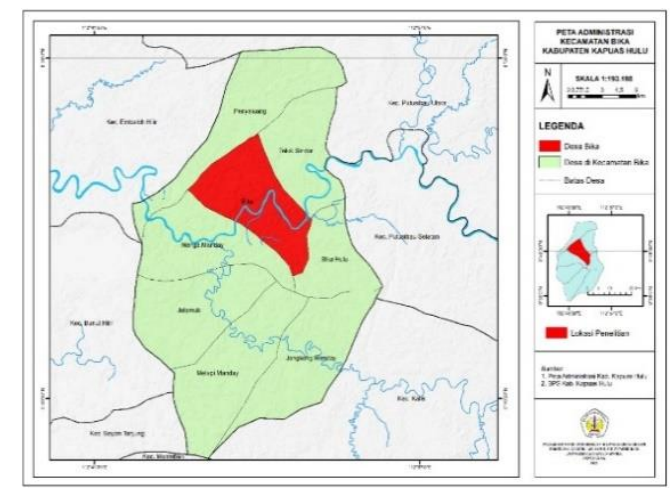

The informants were 9 people, namely

2 village officials, 1 customary leader, 2 religious leaders, 1 head of RT. The researcher felt that the informants obtained were not valid, so the researchers added several informants, namely 2 native Dayak Kantuk people and 1 immigrant community in Bika Village.

Data collection was carried out in April - May 2021. Data were collected from field observations and structured interviews by focusing on the lives and local wisdom of the informants. The interview questions of the Dayak Kantuk community are related to the culture of citizenship and community activities in the values of local wisdom. Interviews were conducted in Indonesian. An in-depth study was conducted as a researcher's effort to understand local wisdom that is still being preserved by the community today through a civic culture (Taylor et al., 2015). The collected data is then reduced, summarized, and selected essential points focusing on the crucial things. In data reduction, researchers only focused on matters related to citizenship culture in the values of local wisdom of the Dayak Kantuk community in Bika Village to make it easier for researchers to conduct further data collection. In interviews and documentation were collected for descriptive analysis. Descriptive data are taken from oral or written questions about observable local wisdom (Rutten \& Soetaert, 2013).

Researchers observed directly in the social environment of the community by interacting with informants in Bika Village. In addition, researchers conducted documentation to strengthen the study results, including photos, videos, sound recordings in the Dayak Kantuk community in Bika Village.

Researchers carry out finding the truth of the data and compiling the data obtained from the results of observations, interviews, and documentation. This is done by organizing the data to sort out what is essential and can be studied, concluding so that researchers can understand it well (Norman k. Denzin, 2009). After collecting the data, the researchers analyzed to validate the data by triangulation. Triangulation intends to be a combination of data collected from various sources, analytical techniques, 
and validations that have been collected (Creswell, 2014).

The data analysis technique used in this research is an interactive model. This interactive model consists of three main things, as stated by (Miles et al., 2014). In qualitative research, there are three ways to analyze data: data reduction, data presentation, and data conclusion drawing. This process was carried out continuously during the research, even before the data were collected entirely, judging from the conceptual framework of the research, research problems, and the data collection approach chosen by the research.

\section{DISCUSSION}

Bika Village Community Solidarity in Preparing Gawai Makai Taun

Preparation of gawai makai taun of the Dayak Kantuk community as a traditional rice safety feast as gratitude for the plants that are the staple food of the Dayak people. In this study, researchers have made observations in Bika Village about preparation in the gawai tradition of the Dayak Kantuk community (Ade \& Affandi, 2016). Gawai makai taun has been around for a long time in the life of the people in Bika Village. This gawai contains elements of a family spirit, and family members work together. Please help prepare materials in the form of food, drinks, and prepare materials for the ritual of pegelak used before the day of the gawai (Fusnika \& Dua, 2019). Community members believe this ritual in Bika Village because it is considered to be able to free the community from evil spirits. Gawai makai taun also contain religious values. The gawai teaches to be grateful for the blessings and fortune that Jubata gives in the form of rice harvests. This kind of preparation invites families who are far away to come, prepare ingredients for cooking such as rice, side dishes consisting of vegetables, chicken, pork, and typical Dayak drinks such as arak, bram, which contain alcohol, and make lemang (sticky rice) cooked in bamboo which will be served to guests and families who come. Preparing a pegelak ritual to purify agricultural tools to avoid evil spirits.

The implementation of the gawai makai taun has a positive impact on people's lives so that the existing culture continues to be developed and preserved by the community, and the gawai makai taun is defined as a traditional rice safety feast with an expression of gratitude to the creator (God) for the agricultural products that have been obtained. This gawai is done after the harvest lasts for 37 days. The tools used in this ritual are agricultural tools sprinkled with the blood of the victim's animal and accompanied by the reading of mantras by traditional stakeholders who the community has trusted.

It is expressed by Heri (pseudonym) that:

This gawai has existed from our ancestors, and we need to continue it. We also feel that with this device, hatred and envy are 
reduced so that we relatives and families help each other to help each other in preparing the materials needed when using the device. Such as inviting family who is far away to come, preparing ingredients for cooking such as rice, side dishes consisting of vegetables, chicken, pork, and typical Dayak drinks such as arak, bram, which contain alcohol, and make lemang (glutinous rice). Which is cooked in bamboo which will be served to guests and families who come. The existence of this gawai tradition implies the spirit of kinship and brotherhood in eating together, visiting each other from one house to another, and from one village to another (Interview 12 April 2021).

The Dayak Kantuk community prepares ingredients in food, drinks, and side dishes needed before gawai day. The spirit of kinship grown by the community certainly makes it easier for people to interact with each other in a family manner without discriminating between one another. Every year the gawai tradition in Bika Village is carried out compactly. There are no differences in ethnicity and religion, and there is a spirit of kinship between villagers. This condition must continue to be preserved as a noble value for a multicultural society. Makai Taun the traditional rice safety feast, the ritual of the Dayak Nyengkelan Batu, machetes, axes, and pickaxes, and the tools used when farming to ensure the agricultural equipment is purified so that the farmers are freed from calamities and disturbances in using these tools for work. As described by Yaso (pseudonym) that:

Prepare materials for local traditional ritual ceremonies. Therefore, to prepare these materials, we as family members carry out the ritual to remove the tools we use for farming. These tools include machetes, axes, pickaxes, and heirlooms that we keep. We call this event nyengkelan batu (purifying farming tools and heirlooms). The intention and purpose of the ritual are to obtain a large fortune, long life, free from harm. That is the content of prayer to the power of the giver of life to us humans to free us from bad luck. Farm tools that have been purified can be used the following year and are not harmful to the cultivators who use them (Interview 13 April 2021).

The interview results show that Nyengkelan Batu is a form of asking for prayer to Petara Jubata according to community belief, thanking them for the harvest they get, and asking for safety and welfare to avoid being disturbed by evil spirits. This ritual is prevalent and must be carried out in all areas inhabited by the Dayak community, especially the Kantuk Dayak tribe. These agricultural tools are not used by anyone except those who can work and are responsible for their work, so children are strictly prohibited from holding and using instruments used by their parents to work.

Figure 1. Heirloom Instruments in the Implementation of the Gawai Makai Taun

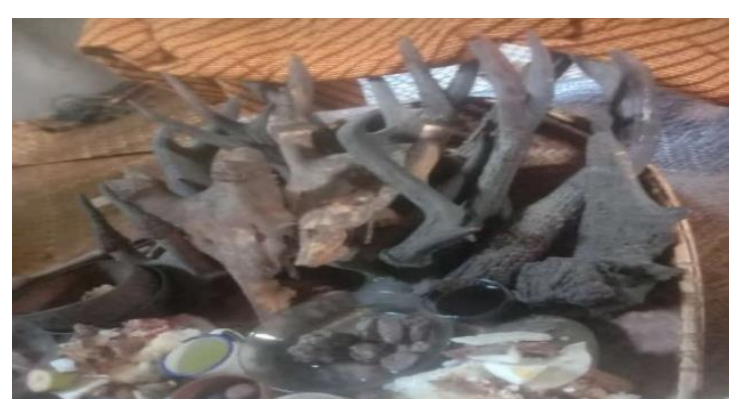

Figure 1. above is an heirloom issued on the day of the gawai. This item will be cleaned because it is mystical according to the beliefs of every community that still carry on the beliefs passed down by their ancestors. 
Usually, a mantra is recited by parents trusted by people who still hold cultural customs. The spell uses a pegelak ritual to summon ancestral spirits to inform him that the gawai makai taun will soon be implemented

\begin{tabular}{|c|c|c|}
\hline Indicator & $\begin{array}{l}\text { Forms } \\
\text { of } \\
\text { activity }\end{array}$ & Description \\
\hline $\begin{array}{l}\text { Forms of } \\
\text { activity }\end{array}$ & $\begin{array}{l}\text { Gawai } \\
\text { makai } \\
\text { taun }\end{array}$ & $\begin{array}{l}\text { The traditional } \\
\text { rice salvation } \\
\text { festival gives life } \\
\text { to rice as a plant } \\
\text { which is the } \\
\text { staple food of the } \\
\text { community }\end{array}$ \\
\hline Purpose & $\begin{array}{l}\text { With the } \\
\text { hope that } \\
\text { in the } \\
\text { followin } \\
\mathrm{g} \text { year, } \\
\text { people } \\
\text { will still } \\
\text { be able } \\
\text { to enjoy } \\
\text { the same } \\
\text { fortune } \\
\text { as the } \\
\text { abundant } \\
\text { rice } \\
\text { harvest }\end{array}$ & $\begin{array}{l}\text { The community } \\
\text { holds } \\
\text { a pegelak ritual } \\
\text { which is a } \\
\text { community belief } \\
\text { to summon } \\
\text { ancestral spirits, } \\
\text { the goal is that the } \\
\text { implementation } \\
\text { of the gawai } \\
\text { makai taun can } \\
\text { run smoothly } \\
\text { during the gawai } \\
\text { process. The } \\
\text { community } \\
\text { also nyengkelan } \\
\text { or cleans the tools } \\
\text { used in farming } \\
\text { and heirloom } \\
\text { tools. }\end{array}$ \\
\hline $\begin{array}{l}\text { Communit } \\
\text { y } \\
\text { participatio } \\
\text { n rate }\end{array}$ & $\begin{array}{l}\text { The } \\
\text { routine } \\
\text { of the } \\
\text { gawai } \\
\text { tradition } \\
\text { every } \\
\text { year }\end{array}$ & $\begin{array}{lr}\text { Prepare } & \text { the } \\
\text { ingredients } \\
\text { needed for gawai } \\
\text { such as pork, } \\
\text { chicken, rice, } \\
\text { Bram, and } \\
\text { alcohol- } \\
\text { containing } \\
\text { alcohol } \\
\text { vegetables. and }\end{array}$ \\
\hline
\end{tabular}

The table above describes in detail the implementation of gawai Makai Taun, which leads to the form of activities, objectives, levels of community participation, and forms of unity. This gawai makai taun shows the results of what the community has done and has a positive impact on developing local wisdom.

\section{Gawai Makai Taun as an impetus to carry out the Bika Village Pegelak Ritual}

The pegelak ritual is used to feed seeds according to the belief of the Dayak people. In general, rice plants, especially rice, have a soul and spirit to live and always live. Hence, the traditional rice salvation ritual for the Dayak people is mandatory for every Makai taun device (Korniadi \& Purwanto, 2019). The purpose and objective of the ritual of the traditional rice salvation festival are to give life force to rice as a plant which is a typical plant and staple food of the Dayak people. From the ritual of the traditional rice salvation party, the Dayaks hope for abundant rice yields in the following year. According to Tito's (pseudonym) expression that:

"Gawai Makai taun" is the highlight of the gawai event that must be celebrated every 5th month (May). Because, after the rice harvest, the people thresh the rice after that, the people celebrate the "gawai". In carrying out the Gawai, the community holds a ritual because it is a custom and culture that must be carried out. The Ritual is often asked if there is a special event carried out in the ceremony. Still, a customary leader who is trusted to carry out the tradition replied that there is no special event. Still, it must be done according to the beliefs of the Dayak community. The ingredients needed for the ritual are natural products consisting of red glutinous rice, white 
rice, black rice, Amur rice, salt, sugar, coconut, banana, betel nut, cigarettes, freerange chicken eggs, and Bram/Tuak. The community carries out the ritual to ask God so that the community can obtain abundant rice yields and be free from harm in the following year. The ritual materials can be more but not less. Therefore, it must be prepared and equipped properly (Interview 13 April 2021).

Reading the Pegelak mantra involves choosing (clean hands and feet) and can read the spell (pegelak), usually an older person. Then "Bedera" is interpreted by reading a prayer and throwing offerings (pegelak) in the doorway (тиа pintu) then hanging pegelak arranged in a lingkang rancak (Rancak is woven bamboo made like a bowl) above the place to store goods which are considered sacred (stone umai) which are usually held in pasah or gentung, timbang.

Furthermore, the gawai tradition in shaping the citizenship culture of the Dayak Kantuk community in Bika Village builds parallel relations between fellow communities, such as always carrying out mutual cooperation in society and holding deliberations that contain the principal solidarity value people's lives (Hatta, 2016). On the other hand, if contextualized in Citizenship Culture, the gawai tradition contains social values. This phenomenon can be proven by having meals with the community in Bika Village, holding deliberation/consensus to evaluate gawai activities, both those that will be implemented and those that have already been implemented (Korniadi \& Purwanto, 2019).

\section{The Process of Implementing the Gawai Makai Taun for the Bika Village Community}

The gawai makai taun process is carried out in the form of community gratitude to God for the blessings and fortune given in the form of being grateful for the abundant rice harvest. Therefore, every family besumai (cook) all vegetables, rice, side dishes that will be served to guests, welcome guests to come, serve special foods for sleepy people such as glutinous rice cooked in bamboo (lemang), cakes made of glutinous flour coated with banana leaves and take out drinks that have been made a month before the gawai takes place, such as Bram, tuak nau, and arak containing alcohol as a community tradition before gawai day.

Before the community implements the Bika Village Gawai, they hold a traditional meeting and deliberation with the community and the Bika Village Dayak Indigenous leaders, which are held 1 (one) month before the implementation of the gawai by forming a committee. The gawai makai taun event runs after the set date and is carried out by the celebrating community. With activities carried out by the community before gawai, such as making typical Dayak drinks such as Bram, tuak nau and arak prepared a month before gawai day, making Dayak specialties made of glutinous rice cooked in bamboo, cooking side dishes consisting of rice, chicken, pork and vegetables that will be served to guests and relatives who come. The Ngemparu 
Nemiak event usually accompanies the Gawai Makai Taun event in Bika Village; guests from Bika Village and other neighboring villages come and enliven the Gawai Makai Taun event. Most youth and parents gathered and enlivened the Gawai Makai Taun event. The younger generations gather together and visit each other without discriminating. The Gawai Makan Tahun ends after the evening, the guests and the community go home with souvenirs, both drinks, and traditional food.

Efforts made by the community in maintaining the gawai tradition are by always encouraging traditional stakeholders, the community, and involving all existing elements to continue to maintain and preserve the culture handed down by the ancestors who became local wisdom in Bika Village. As stated by Juleha (pseudonym) that:

We as a community always participate in cooperation activities that are shoulder to shoulder/help in the gawai tradition. "Gotong royong" is a routine activity that we do. gawai to positively impact people's lives, such as reducing disagreements in our lives that live side by side. We work together in cooperation, regardless of their different backgrounds. There is no distinguishing characteristic, and whether they are from the upper class or the lower class, they are all the same. We even joked with each other and greeted each other while working so that the work didn't feel heavy. This cooperation is also able to foster a voluntary attitude, help, togetherness, and kinship between fellow beings (Interview 17 April 2021).

The behavior of the Dayak Kantuk community prioritizes unity that involves all members of the community as a form of community awareness of the importance of harmony, peace, and togetherness. The implementation of this device is to increase the sense of brotherhood among the Dayak Kantuk community involved in the gawai's performance.

Figure 2. Community Activities Preparing Gawai Makai Taun

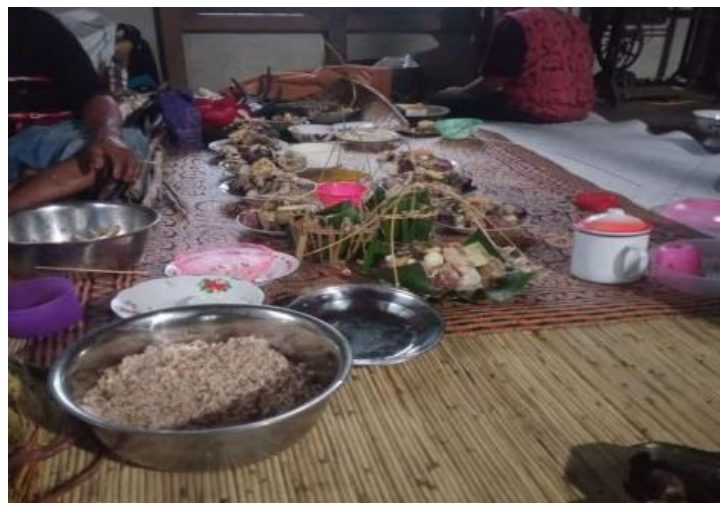

In Figure 2. it looks like food, drinks, and other ritual materials, such as chicken, pork, arak, tuak, red pulut, white pulut, black pulut, cucumber seed, jawak, lingkau lecit, nasik amur, salt, sugar, coconut, banana, betel nut, cigarettes, free-range chicken eggs, and palm wine. This preparation is served in front of the traditional holders, family members, and guests who come. After that, the chants are read by the traditional leaders who the family trusts. Gawai Makai taun provides understanding to the community to live side by side in society without any problems caused. This gawai tradition also gives a positive message to the social life of the people in Bika Village (Hatta, 2016). This device is used as a rope to stay in touch with the Dayak community. At the time of its implementation, 
all community members gather and meet to establish interaction and communication that can strengthen the ties of brotherhood among the Dayak community people. During the gawai tradition process, all Dayak Kantuk communities are required to work together and help each other so that it impacts the community's mutual cooperation attitude.

The Gawai Makai Taun Tradition in Shaping the Citizenship Culture of the Dayak Kantuk Community in Bika Village

The Gawai Makai Taun and the Dayak Kantuk community foster a sense of kinship and tolerance for the younger generation to respect and appreciate each other by visiting each other's homes; an attitude of courtesy is seen during Gawai where young people in Bika Village visit each other's relatives. (Panjaitan \& Sundawa, 2016). On the other hand, the implementation of Gawai Makan Taun is entwined with brotherhood and unity. It is clear that Gawai Makan Taun positively impacts the younger generation and parents and traditional stakeholders in Bika Village. In addition, gawai are activities that have the meaning and value of solidarity and mutual cooperation, which is very important to maintain because it has moral values and values of local wisdom in Bika Village are essential to preserving culture in Bika Village, especially the Dayak Tribe (Fusnika \& Dua, 2019). Apart from that, the customs are translated into the Gawai tradition, which is often carried out by the community from the 90s until now called gawai makai taun. This gawai has a religious element, an expression of gratitude, family gathering together, and mutual cooperation helps prepare the device and tolerance without discriminating between one another (Efriani, Dewantara, et al., 2020).

Gawai Makai Taun is a traditional rice safety party to give life to rice as a plant, a typical plant and staple food of the community. The Gawai Makai Taun activity has a series of exercises. Before the implementation, the entire Dayak Kantuk community prepares the materials needed for the gawai such as pork, chicken, rice, vegetables, and drinks such as Bram and arak containing alcohol and invites distant families to come. Apart from all that, the community also prepares a pegelak ritual which is believed by the community as something that must be carried out so that the community is free from danger and when farming is protected from interference by evil spirits (Hatta, 2016).

Pegelak rituals are carried out at the gawai makai taun ceremony, especially those related to fields and rice. Practices are carried out during the year the device lasts. On the day of the gawai, a ceremony is held to summon ancestral spirits to inform Him that the gawai makai taun will soon be carried out. This pegelak ritual ceremony aims to notify the intention of the gawai makai taun to be carried out. After informing the purpose, the customary holder is sent to recite a mantra that each family member trusts to ask for protection 
and blessings to the ancestral spirits so that the gawai makai taun party can run well. In the ceremony, the traditional holder reads a prayer or some mantra that the traditional holder can only interpret (Efriani, Praptantya, et al., 2020).

\section{Barriers to the Dayak Kantuk Community in Preserving Gawai Makai Taun}

The implementation of the Gawai traditional ceremony can impact the social life of the Dayak community in Bika Village. Gawai is a traditional ceremony that is held regularly every year. This, of course, can be the right solution to overcome the obstacles faced in preserving the values of local wisdom of the Dayak Kantuk Community (Ade \& Affandi, 2016). However, it is considered sacred at the Gawai traditional ceremony, which only involves the Dayak tribe. Still, as the times progressed, at this time, the Gawai traditional ceremony was included in the Cultural festival schedule, which was held once a year (Prayogi \& Danial, 2016). So the Gawai traditional ceremony can be witnessed by anyone outside the Dayak tribe. The persistence of the traditional gawai ceremony is proof that gawai have become a tradition for the Dayak community in Bika Village. Gawai is a necessary medium to refresh the sense of solidarity and kinship among fellow individuals in the Dayak community (Elyta, 2021).

The Dayak Kantuk community is one of the tribes that prioritize their beliefs by carrying out various traditional ceremonial rituals. The Dayak tribe holds traditional ceremonial rituals that have meaning because the rituals that the Kantuk community goes through have a function and purpose. One of the Dayak rituals routinely carried out every year is the pegelak ritual carried out on the day before Gawai Makai Taun. Gawai Makai Taun is one of the traditional ceremonies that aims as a form of expression of gratitude for the community (Elyta, 2021). Therefore this Gawai has become a traditional tradition present amid people's lives that has long been necessary and must be maintained; all this is because the Gawai Makai Taun has a role and function in maintaining a sense of solidarity between individuals, especially the Dayak Kantuk tribe (Couldry et al., 2014).

In the gawai makai taun tradition, it also has a vital role to be preserved by all ethnic groups, which are the local identity of the community (Panjaitan \& Sundawa, 2016). Like the Dayak Kantuk, they experience obstacles to changes in the socio-economic field. Socio-economic conditions, especially the level of prosperity, have a considerable influence on the pattern of life and culture. Economic prosperity gives creative freedom, provides freedom of action and choice. The development of human resources has influenced the current condition of the Dayak Kebahan economy (Herlan et al., 2020). The role of various independent businesses outside of farming has been developed. The Dayak 
Kantuk has carried different professions outside of farmers. Various socio-economic empowerments, such as the people's credit system, trade system, production, and distribution system, are now familiar to most Dayaks Kantuk. For the Dayak community, economics is an obstacle in implementing the gawai makai taun. In carrying out the gawai, the district has to spend a lot of money to buy the necessities used before gawai takes place (Ermawan. T., 2017). However, apart from this phenomenon, this gawai makai taun is not coercive because it can be implemented simply to preserve customs and culture.

Gawai makai taun is very important to be maintained and preserved to maintain cultural customs and build solidarity between fellow communities through cooperation and solidarity between individuals in the preparation and implementation of Gawai Makai Taun that still exists in the Dayak Kantuk community (Vatria et al., 2015). The Gawai tradition is considered necessary by people who have a source of inspiration for the community to organize life together. This is undoubtedly a benchmark in determining every society's attitude and manners in the Dayak tribe. Cooperation that exists between communities can strengthen the sense of solidarity so that the moral function contained in the Gawai ceremony can affect all aspects of people's lives, especially in building kinship between fellow Dayak people, both challenges from internal and external elements as well as in the form of actions and thoughts of the community.

\section{CONCLUSION}

Preparation in the Gawai Makai Taun tradition of the Dayak Kantuk community fosters a sense of tolerance for mutual respect and respect by visiting the rules of the Bika Village community. Members of the community trust this ritual because this ritual is considered to be able to free us from evil spirits. This implementation causes the pegelak ritual to be used to ngumpan benih according to the Dayak belief in rice plants. On the other hand, the gawai makai taun process is carried out in the form of community gratitude to God for the blessings and fortune given in the form of being grateful for the abundant rice harvest. The gawai makai taun tradition of the Dayak Kantuk community fosters a sense of kinship and tolerance for the younger generation to respect and appreciate each other by visiting each other's homes. An attitude of courtesy is seen during gawai where youths in Bika Village visit relatives. Efforts made by the community in maintaining the gawai tradition by encouraging traditional stakeholders, the community and involving all elements in the community to preserve the culture handed down by their ancestors.

\section{REFERENCES}

[1] Ade, V., \& Affandi, I. (2016). Implementasi 
Nilai-Nilai Kearifan Lokal Dalam Mengembangkan Keterampilan Kewarganegaraan (Studi Deskriptif Analitik Pada Masyarakat Talang Mamak Kec. Rakit Kulim, Kab. Indragiri Hulu Provinsi Riau). Jurnal Pendidikan Ilmu Sosial, 25(1), 77. https://doi.org/10.17509/jpis.v25i1.3671

[2] B.miles, M., Huberman, A. michael, \& johnny saldana. (2014). No Title. Qualitative Data Analysis A Methods Sourcebook, edition 3.

[3] Bahri, S. (2015). Gawai Dayak sebagai Sumber Sejarah Lokal Tradisi Masyarakat Indonesia Sebelum Mengenal Tulisan. SOCIA: Jurnal Ilmu-Ilmu Sosial, 12(2). https://doi.org/10.21831/socia.v12i2.12236

[4] Couldry, N., Stephansen, H., Fotopoulou, A., MacDonald, R., Clark, W., \& Dickens, L. (2014). Digital citizenship? Narrative exchange and the changing terms of civic culture. Citizenship Studies, 18(6-7), 615-629. https://doi.org/10.1080/13621025.2013.86590 $\underline{3}$

[5] Creswell, J. W. (2014). Research Design Pendekatan Kualitatif, Kuantitatif, dan Mixed. (4th ed.). SAGE Publications.

[6] Donny Ermawan. T., M. D. . (2017). Pengaruh Globalisasi terhadap Eksistensi Daerah di Kebudayaan Indonesia Meningkatkan Peran Pemimpin Visioner untuk Mewujudkan Tata Kelola Pemerintahan yang Baik ( Good Governance ) Pengembangan Ekonomi Kreatif dan Berbasis Iptek dalam Mewujudkan Ketahanan.

[7] Efriani, E., Dewantara, J. A., Praptantya, D. B., Darmawan, D. R., \& Hijjang, P. (2020). Maskawin sebagai Pertahanan Strata Sosial Samagat Etnik Dayak Tamambaloh. ETNOREFLIKA: Jurnal Sosial Dan Budaya, 9(1), $1-14$. https://doi.org/10.33772/etnoreflika.v9i1.719

[8] Efriani, E., Praptantya, D. B., \& Dewantara, J. A. (2020). Dange: Jurnal Masyarakat Dan Budaya, 22(2), 167-176. https://doi.org/10.14203/jmb.v22i2.1076

[9] Elyta, E. (2021). Gawai Dayak Festival and the Increase of Foreign Tourist Visits. Jurnal Global \& Strategis, 15(1), 167. https://doi.org/10.20473/jgs.15.1.2021.167186
[10] Feriandi, Y. A. (2017). Revitalisasi moral kewarganegaraan dalam ungkapan Jawa sebagai sumber pembentukan civic culture dan politic culture. 14.

[11] Fusnika, \& Dua, F. L. (2019). Kontribusi Budaya Lokal Gawai Dalam Menumbuhkan. Jurnal Pekan, 4(2), 149-158.

[12] Hatta, S. (2016). Nilai-Nilai Solidaritas Generasi Muda Simeon Hatta. Program Studi Pendidikan Sosiologi Jurusan Pendidikan Ilmu Ilmu Sosial Fakultas Keguruan Dan Ilmu Pendidikan Universitas Tanjungpura Pontianak, 1-11.

[13] Haybi-B M., \& Shoshana, A. (2021). Ethnic mobility: ethno-class identities and selfnegation. Journal of Social Identities, 27(3), 326-341.

https://doi.org/10.1080/13504630.2020.18227 $\underline{96}$

[14] Herlan, H., Praptantya, D. B., Juliansyah, V., Efriani, E., \& Dewantara, J. A. (2020). Konsep Sehat dan Sakit pada Budaya Etnis Dayak Kebahan. ETNOREFLIKA: Jurnal Sosial Dan Budaya, 9(1), 24-38. https://doi.org/10.33772/etnoreflika.v9i1.720

[15] Korniadi, K., \& Purwanto, P. (2019). Analisis Nilai Karakter Tradisi Wiwitan Dalam Perspektif Kearifan Lokal Di Desa Sumberejo, Kecamatan Jatisrono, Kabupaten Wonogiri. Civics Education and Social Science Journal (Cessj), 1(1), 55-67. https://doi.org/10.32585/cessj.v1i1.358

[16] Levada, Y. A. (2018). Civic culture. In Russian Culture at the Crossroads: Paradoxes of Postcommunist Consciousness (pp. 299-312). https://doi.org/10.4324/9780429497506

[17] Norman k. Denzin. (2009). No Title. Taylor \& Francis, A theoretical introduction to sociological methods, 361.

[18] Panjaitan, L. M., \& Sundawa, D. (2016). Pelestarian Nilai-Nilai Civic Culture dalam Memperkuat Identitas Budaya Masyarakat: Makna Simbolik Ulos dalam Pelaksanaan Perkawinan Masyarakat Batak Toba di Sitorang. Journal of Urban Society's Arts, $3(2)$, https://doi.org/10.24821/jousa.v3i2.1481

[19] Prayogi, R., \& Danial, E. (2016). Pergeseran Nilai-Nilai Budaya Pada Suku Bonai Sebagai 
Civic Culture Di Kecamatan Bonai Darussalam Kabupaten Rokan Hulu Provinsi Riau. Humanika, 23(1). https://doi.org/10.14710/humanika.v23i1.117 $\underline{64}$

[20] Rutten, K., \& Soetaert, R. (2013). Critical Arts : South-North Cultural and Media Studies Literacy narratives as ethnography Literacy narratives as ethnography. January 2015, 3741.

https://doi.org/10.1080/02560046.2013.86758 $\underline{8}$

[21] Taylor, steven J., Bogdan, R., \& Devault, M. L. (2015). No Title. Introduction to Qualitative Research Methods: A Guidebook and Resource/Taylor, Steven J. Bogdan, Robert Devault, Marjorie L.Davault.-4th Edition.

[22] Vatria, Y., Amir, A., \& Syahrani, A. (2015). Leksikon budaya dalam hukum adat masyarakat dayak kantuk kecamatan putussibau utara kabupaten kapuas hulu. Pendidikan Dan Kebudayaan, 1-8.

[23] Wang, L. jung. (2014). Cultural rights and citizenship in cultural policy: Taiwan and China. International Journal of Cultural Policy, 20(1), 21-39. https://doi.org/10.1080/10286632.2012.72982 $\underline{3}$

[24] Yosi Malasari, (2017). Budaya Adat Pengantin Melayu Riau Dalam Pengembangan Budaya Kewarganegaraan. Humanika, 24(1) 